\title{
Stem heat balance method to estimate transpiration of young orange and mango plants
}

\author{
Lucas M. Vellame ${ }^{1}$, Maurício A. Coelho Filho ${ }^{2}$, Vital P. S. Paz ${ }^{3}$ \& Eugênio F. Coelho ${ }^{2}$
}

\begin{abstract}
The present study had as its main objective the evaluation of the heat balance method in young orange and mango plants under protected environment. The work was carried out at Embrapa Cassava and Tropical Fruits, Cruz das Almas, BA. Later on, estimates of sap flow were conducted for two mango plants cultivated in pots of 15 and $50 \mathrm{~L}$ installed on weighting platforms of 45 and $140 \mathrm{~kg}$; sap flow was determined in three orange plants, two of which were also installed on weighing platforms. The values of sap flow were compared to the transpiration measured by lysimeters at integrated intervals of 1, 2, 4 and $24 \mathrm{~h}$. The heat balance method showed good precision for estimating daily transpiration $\left(R^{2}=0.95\right.$ and $R^{2}=0.90$ ), accompaning the availability of energy in the system, underestimating on average $4.6 \%$ of the daily transpiration in orange plants and overestimating in about $0.3 \%$ the daily transpiration of mango plants under conditions of good water supply. The heat balance method underestimated by $16 \%$ the transpiration in orange under conditions of water deficit.
\end{abstract}

Key words: sap flow, lysimeters, citrus, water stress

\section{Balanço de calor caulinar para estimativa da transpiração de plantas jovens de laranja e manga}

\begin{abstract}
RESU MO
Com o presente estudo se objetivou avaliar o método de balanço de calor em plantas jovens de laranja e manga em ambiente protegido. 0 trabalho foi conduzido na Embrapa Mandioca e Fruticultura, Cruz das Almas, BA. Realizaram-se estimativas de fluxo de seiva em duas plantas de manga plantadas em vasos de 15 e $50 \mathrm{~L}$, instalados sobre plataformas de pesagem de 45 e 140 kg; posteriormente, o fluxo de seiva foi determinado em três plantas de laranja, duas também instaladas em lisímetros de pesagem. $0 \mathrm{~s}$ valores de fluxo de seiva obtidos foram comparados com a transpiração medida pelos lisímetros em intervalos de integração de 1, 2, 4 e $24 \mathrm{~h} .0$ método do balanço de calor mostrou-se preciso na estimativa da transpiração diária $\left(\mathrm{R}^{2}=0,95\right.$ e $\left.\mathrm{R}^{2}=0,90\right)$, que acompanhou a disponibilidade de energia do sistema, subestimando em média, 4,6\% a transpiração diária em plantas de laranja e superestimando em média 0,3\% no caso das plantas de manga quando em condições de boa disponibilidade de água no solo. Em condições de baixa disponibilidade hídrica o método do balanço de calor subestimou em $16 \%$ a transpiração em laranja.
\end{abstract}

Palavras-chave: fluxo de seiva, lisímetros, citros, estresse hídrico

1 Pós graduação em Irrigação e D renagem ESALQ/U SP. Av. Pádua Dias, 11, CP 9, CEP 13418-900, Piracicaba, SP. Fone: (19) 3447-8551. E-mail: lucasvellame@gmail.com 2 Embrapa Mandioca e Fruticultura Tropical, Rua Embrapa, CP 07, CEP 44380-000, Cruz das Almas, BA. Fone: (75) 3621-8021. E-mail: macoelho@cnpmf.embrapa.br, ecoelho@cnpmf.embrapa.br

${ }^{3}$ Centro de Ciências Agrárias/U FRB, Rua Escola de Agronomia, CEP 44380-000, Cruz das Almas, BA. Fone: (75) 3621-2120. E-mail: vpspaz@gmail.com 


\section{INTRODUCTION}

In irrigated agriculture it is important to minimize water losses by percolation and runoff. In addition to wasting water and the energy for its pumping, water in excess can leach the fertilizers applied to aquifers; thereby causing pollution. At the same time, adequate irrigation is necessary to keep soil moisture ideal for good plant growth, ensuring economic viability. Transpiration is the main element of evapotranspiration component in microirrigated systems because water is applied to only some parts of an area. It is extremely important to determine the quantity of water used in irrigation, especially for the irrigation of fruit trees, where this system has been widely used.

Among the alternatives employed to determine the transpiration in the field, gas chambers, which include porometers, are widely used today, but they have problems in measuring interferences in the stomatal response of plants because of the disturbance in air caused while introducing the leaf into measurement chambers, with measurement representativeness of measurements and also because of impossibility of automation. Lysimeter technique has limitations, especially manifested in the case of large trees; the main constraint of which is the high cost of the equipment required, which makes it difficult to reproduce the experiments. Methodologies for determining the water consumption by the trees, such as the water balance in the soil, may result in inconsistent information due to the great heterogeneity of the root system, the variability of soil variables and the accuracy in determining the soil moisture. This renders the method difficult to use, especially on the daily scale.

Currently, most studies on plant transpiration measurements are based on methods of providing heat in the trunk. Sensors are fixed or placed on the trunk or the branches of plant so that sap flow can be measured for a period of $24 \mathrm{~h}$, which is closely related to transpiration (Coelho Filho et al., 2005b; Delgado-Rojas et al., 2007; Vellame et al., 2009). To determine sap flow (transpiration), methods based on heat supply pulses to the trunk (Cohen et al., 1981) under continuous heat supply, as happens in the case of the method of thermal probe dissipation (Granier, 1985) and in the method of heat balance (Sakuratani, 1981).

The methods mentioned above are well known for their non-destructive characteristics and for permitting the concurrent study of transpiration in a variety of plants in the field. The method of heat balance has the advantage of not requiring calibration, while the other two, because these measure the density of sap flow, will require the determination of the xylem effective area to transform sap flow density into sap flow. Several authors have applied this method not only in the study of woody plants (Bauerle et al., 2002, Nakai et al., 2005; Marin et al., 2001; Tarara \& Ferguson, 2006), but also in the study of herbaceous plants (Trejo-Chandia, 1997; Gomide et al., 2005).

In apple trees, Weibel \& Vos (1994) studied different measurement intervals with sap flow evaluated transpiration by the heat balance and by lysimeter. Steinberg et al. (1989) determined the errors at different integration times in woody plants. Trejo-Chandia (1997) also compared this method with the transpiration obtained by weighing lysimeter in three species of plants on daily and hourly basis.

Although widely used in scientific research, the precision and accuracy of these methods have not been fully documented. To use safely, it is still necessary that certain aspects of these methods be clarified; for example, those concerning the determination of estimation error for various crops at different stages of development and under different climatic conditions.

This study compares the heat balance method with the lysimetric measurements in young mango and orange plants cultivated in protected environment and tests the method under water deficit conditions.

\section{MATERIAL AND METHODS}

The experiment was conducted at Embrapa Cassava and Tropical Fruits located in Cruz das Almas $\left(12^{\circ} 40^{\prime} \mathrm{S}\right.$, $39^{\circ} 30^{\prime} \mathrm{W}$; altitude $225 \mathrm{~m}$ ). It involved a number of studies on mango and orange crops. The climate of this region is classified as humid, to sub humid with a mean annual rainfall of $1,143 \mathrm{~mm}$.

Orange (cv. Pêra) and mango (cv. Tommy Atkins) seedlings were used for the experiment. Three plants of each species were planted in 15 and 50 L-pots. The study was initiated six months later in order to ensure an adequate root system. The pots were placed on weighing platforms with 45 and $140 \mathrm{~kg}$ capacity. This system worked as weighing lysimeters. Transpiration was calculated directly by mass difference since the soil surface was covered with plastic to prevent evaporation. The maximum errors of the weighing system are shown in Table 1, these errors were detected by means of the test recommended by Wheeler \& Ganji (1996) and applied by Vellame \& Oliveira (2005) and Santos et al. (2006).

The errors presented here are adequate for the present study given their small magnitude and their minimum impact concerning the lack of the repeatibility of the means, having been determined only after many readings.

Table 1. Weighing lysimeter errors

\begin{tabular}{crc}
\hline & \multicolumn{2}{c}{ Error (g) } \\
\cline { 2 - 3 } & \multicolumn{2}{c}{ Lysimeters } \\
\cline { 2 - 3 } Absolute maximum error & $\mathbf{4 5} \mathbf{~ g g}$ & $\mathbf{1 4 0} \mathbf{~ g}$ \\
Repeatibility & 6.530 & 44.650 \\
Hysteresis & 10.310 & 58.360 \\
& 8.840 & 21.460 \\
\hline
\end{tabular}

Commercial heat balance sensors (models SGB9 and SGA13; Dynamax Inc.) were used in two mango plants. Lysimeter sensors were connected to a data acquisation system composed of a datalogger CR10X coupled to a multiplexer AM 416 (Campbell Sci.) which had been set to take readings at intervals of $10 \mathrm{~s}$, and to store the data to determine the means at intervals of $10 \mathrm{~min}$. The measurements were made during the period from 9 to 13 November, 2004. 
From 7 to 30 April , 2005, heat balance sensors (models SGB9, SGA16 and SGA13; Dynamax Inc.) were installed in three orange plants, two of them were monitored by means of weighing lysimeters.

The heat balance method is based on the heat transfer to the tree trunk $\left(\mathrm{P}_{\mathrm{in}}\right)$ and is distributed in the stem segments sampled, in the stored heat $\left(\mathrm{Q}_{\mathrm{s}}\right)$ as heat flow which is transported by the stem both above and below the control volume $\left(Q_{v}\right)$, and by the heat flow radiating from the sensor $\left(Q_{r}\right)$.

The axial flow $(\mathrm{Qv})$ was calculated according to the thermal conductivity of the stem $\left(0.42 \mathrm{~W} \mathrm{~m}^{-1} \mathrm{~K}^{-1}\right)$ and the thermal gradients found at both ends of the stem segment sampled. The stored heat in the stem was disregarded because, in stem diameters inferior to $3 \mathrm{~cm}$ its value is not at all important and brings no difference to the quality of estimates (Weibel \& Vos, 1994). The radial flows $\left(Q_{R}\right)$ were calculated from the knowledge of thermal conductivity of cork substrate $\mathrm{K}_{\mathrm{sh}}$ ), of which the radial flow-meter is made up and from the difference of temperature adjacent to the heating element and the external surface of the cork, determined by means of a thermal battery with alternate joints (flow meter) attached heater. Sap flow was obtained by dividing the residual heat by the specific sap heat $\left(\mathrm{c}_{\mathrm{p}}=4.186 \mathrm{Jg}^{-1} \mathrm{~K}^{-1}\right)$ and by the difference of the sap temperature between the upper and lower boundaries of the heated segment (DT).

The values of $\mathrm{K}_{\mathrm{sh}}$ were calculated by considering the zero flow conditions (from 4 to $5 \mathrm{~h}$ ) and the sap flow (F) calculated by Eq. 1 (Sakuratani, 1981).

$$
\mathrm{F}=\frac{\mathrm{P}_{\mathrm{IN}}-\mathrm{Q}_{\mathrm{V}}-\mathrm{Q}_{\mathrm{R}}}{\mathrm{c}_{\mathrm{P}} \cdot \Delta \mathrm{T}}
$$

The obtained sap flow values were compared with the transpiration measured by the lysimeters by means of linear regression in integration intervals of $1,2,4$ and $24 \mathrm{~h}$.

\section{Determining the sap flow under water deficit conditions}

From the three orange plants cultivated in $15 \mathrm{~L}$ pots, where heat balance sensors were installed, two of them were monitored by weighing lysimeters; and the other was kept under constant groundwater supply by coupling drain of the recipient so as to obtain potential transpiration. This part of the study was carried out during the period of 1 to 10 May, 2005.

Total solar radiation was monitored by means of silica piranometer coupled to the data acquisation system. The soil matric potential was monitared daily by means of tensiometers.

Initially the plants were irrigated bringing the soil at field capacity seven days later irrigation was interrupted in order to verify the sensor's performance under water deficit conditions. Irrigation was restored when the soil matric potential was found to be lower than $-80 \mathrm{kP}$.

In order to compare different plants, the values of transpiration and sap flow were divided by leaf area so that transpiration per leaf unit could be obtained. The orange plants' leaf area (LA) was obtained by measuring the greatest length (L) and width $(\mathrm{W})$ in $10 \%$ of leaves and LA was calculated by
Eq. 2 (Coelho Filho et al., 2005a). The same method was employed with the mango plants, however, the method was applied to all leaves. Leaf area was calculated by Eq. 3 (Oliveira, 2005).

$$
\begin{aligned}
& \mathrm{LA}=0.72 \mathrm{WL} \\
& \mathrm{LA}=0.5646 \mathrm{WL}+4.7508
\end{aligned}
$$

\section{RESULTS AND DISCUSSION}

Figure 1 shows the sap flow and transpiration paths for a period of 5 days in orange and mango plants with leaf areas ranging from 0.82 to $0.45 \mathrm{~m}^{2}$ respectively. It is worth noticing that the two variables had similar behavior throughout the day: both sap flow and transpiration measurements were positive and increased until the highest water demand of the dony decreas, however, late in the afternoon.

As shown in Figure 1, small variations in the dynamic response between the lysimeter measurements and those of sap flow were observed, probably in response to the plants' stomata mechanism, water capacitance of the stem above the sensor and the heat capacitance of the trunk. However, this caused the method to fail to detect fast changes in the transpiration process as discussed by Coelho Filho (2002). Research results involving herbaceous and woody plants demonstrated that the dynamic response obtained from the stem heat balance method varied from 5 to 20 min (Cermark et al., 1984; Steinberg et al., 1989; Trejo-Chandia, 1997).

Figure 2 shows the relationship between transpiration per unit of leaf area in relation to global radiation. Transpiration per-unit leaf area followed the amount of energy available in the system; nevertheless, many factors such as leaf area, atmospheric demand and water availability affect the transpiration process. Coelho Filho (2002) have mentioned, besides these variables, the plantation geometry, the plant spacing and the rootstock may also affect. For this reason, these results may not be used in conditions other than those anticipated by the present study whose main purpose was to assess the stem heat balance method rather than recommend methods of estimating evapotranspiration.

As the results presented in this study are all related to irrigated conditions and water readily available to plants, it was observed that transpiration per unit leaf area in relation to the quantity of available energy was higher in the mango crop, making clear the greater stomata control in citrus crop, contributing as it seems to the research corroborating with the results obtained by Coelho Filho et al. (2004) and Oliveira et al. (2005) who have studied the lime "Tahiti" and the mango plants under field conditions.

Table 2 shows the values of the angular coefficients (a) and those of determination $\left(\mathrm{R}^{2}\right)$ obtained by means of linear regression with forced intercepts for measurements of sap flow and transpiration (lysimeters) of plants.

It is observed that the greater the time interval used for comparisons, the greater is the agreement between the two methods, a trend also verified by Coelho Filho et al. (2005b) in the case of 'Tahiti' lime plants with lysimeters in the field. 


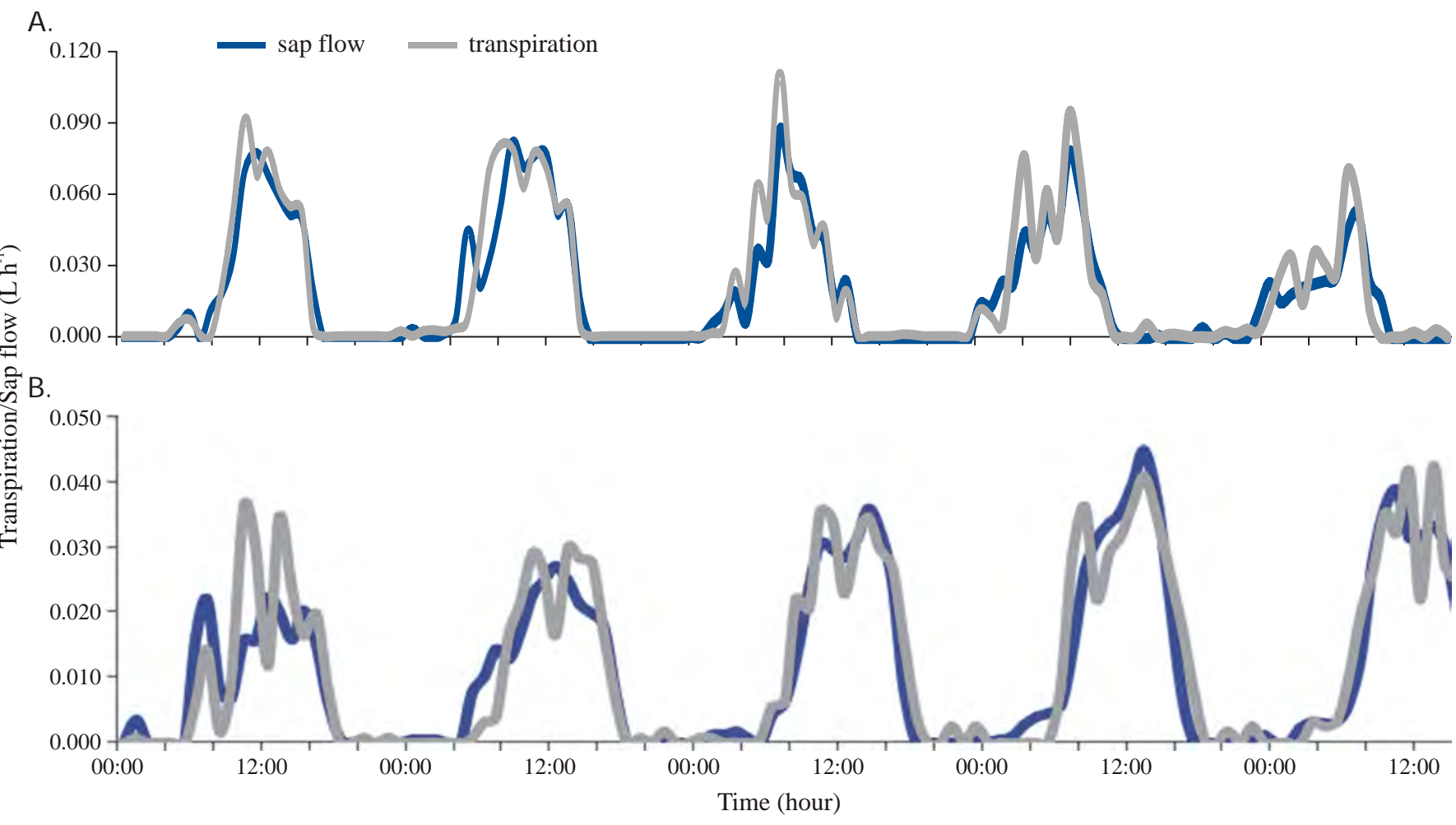

Figure 1. Path of the transpiration measurements taken by means of weighing lysimeters and from sap flow observation, as determined by the stem heat balance method in mango plants $(A)$ and orange plants $(B)$

A.

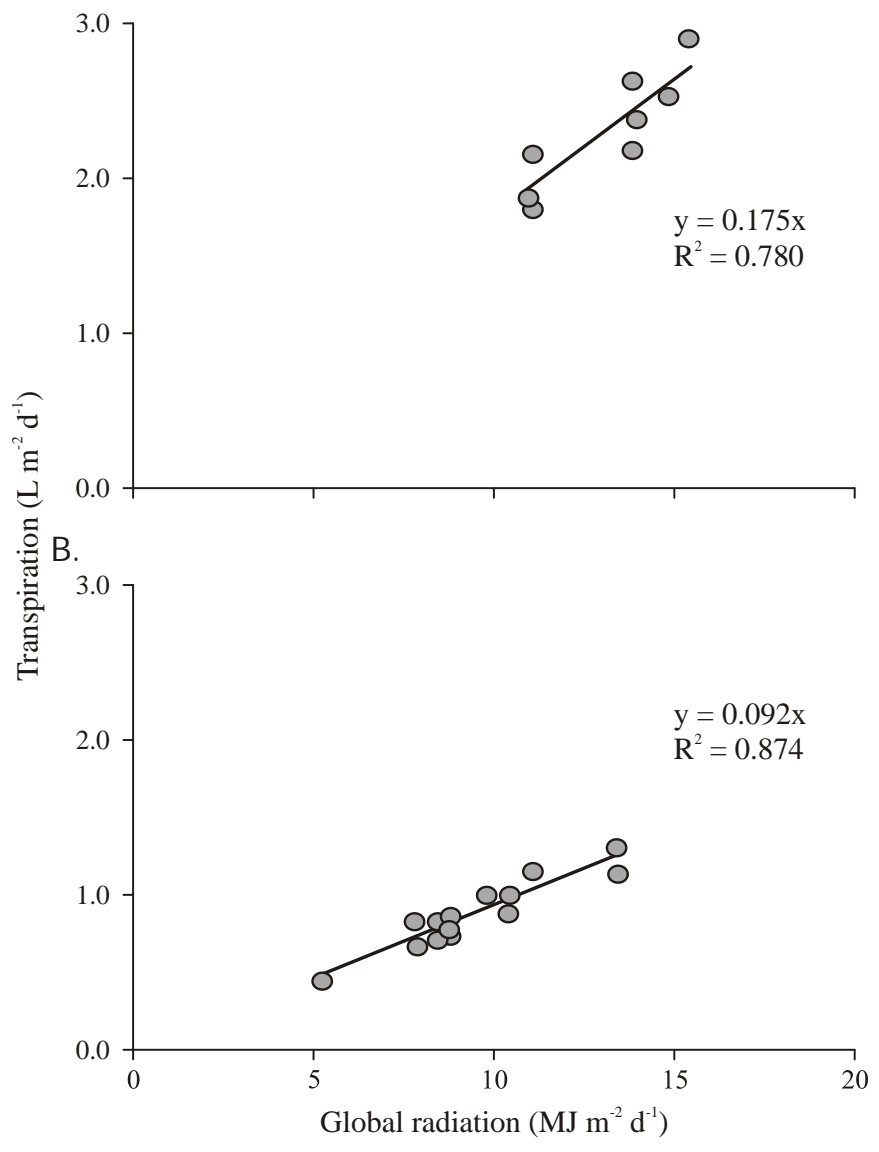

Figure 2. The relation between daily transpiration, as determined by the heat balance method per unit leaf area and by global radiation in mango plants $(A)$ and orange plants (B)
They have attributed this trend to the high punctual transpiration variability in the lysimeters related to the wind action and to the roughness of the plant. Such behavior has been observed on the $1 \mathrm{~h}$ scale in the present study (Figure 1), a possible explanation as to the increasing correlation with the time interval used has to do with the cancelation of the measurement variability referring to both variables around a mid point, as happens when one integrates data with too many points. The stem heat balance method appeared to underestimate the values $(4.6 \%)$ of daily transpiration in orange plants; and overestimate $(0.3 \%)$ them in the case of the mango plants.

Weibel \& Vos (1994) observed in sap flow studies applied to apple trees utilising the heat balance method at short measuring intervals, that considerable errors did occur between the sap flow measured by the transpiration and by heat balance method. The authors have stated that, at intervals greater than $24 \mathrm{~h}$, the error is of $4 \%$; while at shorter intervals (30 min) the error may reach $20 \%$. Steinberg et al.

Table 2. Linear coefficient (a), coefficient of determination $\left(R^{2}\right)$ and the number of observations of linear regression (n) with forced regression coefficient at zero of the sap flow measurements regarding the lysimeter measurements taken from young orange and mango plants at intervals from $1,2,4$ and $24 \mathrm{~h}$

\begin{tabular}{cccccccc}
\hline Integration & \multicolumn{3}{c}{ Orange } & & \multicolumn{3}{c}{ Mango } \\
\cline { 2 - 4 } \cline { 6 - 8 } intervals (hour) & $\mathbf{a}$ & $\mathbf{R}^{\mathbf{2}}$ & $\mathbf{n}$ & & $\mathbf{a}$ & $\mathbf{R}^{\mathbf{2}}$ & $\mathbf{n}$ \\
1 & 0.86 & 0.87 & 1104 & & 0.92 & 0.75 & 240 \\
2 & 0.88 & 0.92 & 552 & & 0.94 & 0.86 & 120 \\
4 & 0.89 & 0.94 & 276 & & 0.97 & 0.91 & 60 \\
24 & 0.95 & 0.96 & 46 & & 1.03 & 0.89 & 10 \\
\hline
\end{tabular}


(1989) have observed in woody plants that when the measurements are integrated at intervals greater than $24 \mathrm{~h}$, the error may be lesser than 4\%. However, Trejo-Chandia (1997), in comparing this method to the transpiration obtained by weighing lysimeters in maize, tomato and young lemon trees found good agreement with approximately $10 \%$ error, both in daily and hourly scales.

Figure 3 shows the relation between transpiration and sap flow under water deficit conditions. Under such conditions there is an increasing tendency of this method to underestimate transpiration in orange plants $(16 \%)$. Absolute errors, however, are small in this case because of the fact that under these conditions transpiration is not significant; the method's precision did not go through greater alterations once the coefficient of determination $\left(\mathrm{R}^{2}\right)$ was 0.9256 , while in normal conditions of potential transpiration, the coefficient showed in Table 2 was 0.9582 .

The tendency of sap flow to underestimate transpiration in cases of high water deficits in the soil (also verified by

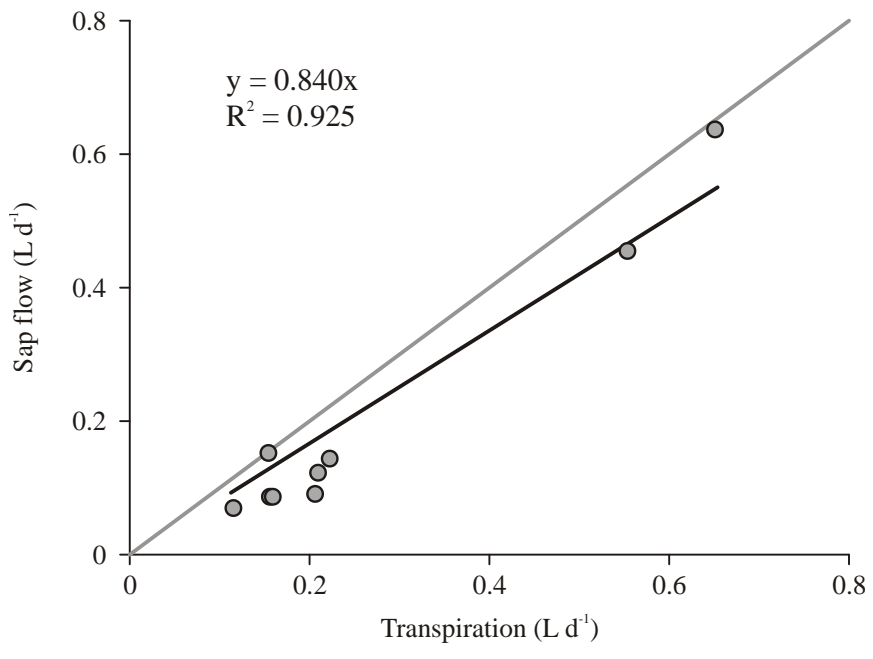

Figure 3. Relation between the transpiration measured by two weighing lysimeters and sap flow determined by the heat balance method in orange plants under conditions of water deficit
Alarcón et al. (2000) in the Prunus Armeniaca culture) may be explained by considering the hydraulic capacitance of tissues allowing for the water loss into the plant's atmosphere without the proper soil replacement (the plant negative water balance in plant), which promotes the reduction of measured mass by the lysimeters; though without stem sap flow. David et al. (1997) comparing the method of heat dissipation in the eucalyptus crop to the evapotranspiration by the Penman-Monteith method, have observed a similar tendency of variations between sap flow and the evapotranspiration under good water conditions, but as the soil became drier, the evapotranspiration became proportionately higher.

Figure 4 shows the path of transpiration per unit leaf area, while Table 3 shows the accumulated transpiration per unit leaf area in an orange plant with adequate water and another in a soil under drying conditions. The matric potential was monitored and on reaching the value $-80 \mathrm{kPa}$ the plant was irrigated. It has been verified, as shown in Table 3, that the accumulated transpirations $\left(\mathrm{L} \mathrm{m}^{-2}\right)$ are higher when determined by lysimeters. It is observed, as Figure 4 shows, that, after irrigation, transpiration was lower in the early morning hours when compared to the values of sap flow, probably due to water replacement in plant tissues. By the end of the day, however, the accumulated transpiration was similar, something that did not happen before.

Table 3. Daily accumulated transpiration per unit leaf area of an orange plant in soil undergoing drying process estimated by the method of sap flow and weighing lysimeters as compared to another plant under adequate water supply (potential sap flow)

\begin{tabular}{cccc}
\hline \multirow{2}{*}{ Date } & \multicolumn{3}{c}{ Daily transpiration per unit leaf area $\left(\mathbf{L ~} \mathbf{~ m}^{-2}\right)$} \\
\cline { 2 - 4 } $5 / 2 / 2005$ & Sap flow & Lysimeters & Potential sap flow \\
$5 / 3 / 2005$ & 0.54 & 0.55 & 0.55 \\
$5 / 4 / 2005$ & 0.49 & 0.54 & 0.95 \\
$5 / 5 / 2005$ & 0.29 & 0.50 & 1.03 \\
$5 / 6 / 2005$ & 0.28 & 0.51 & 1.21 \\
$5 / 7 / 2005$ & 0.23 & 0.38 & 1.10 \\
\hline
\end{tabular}

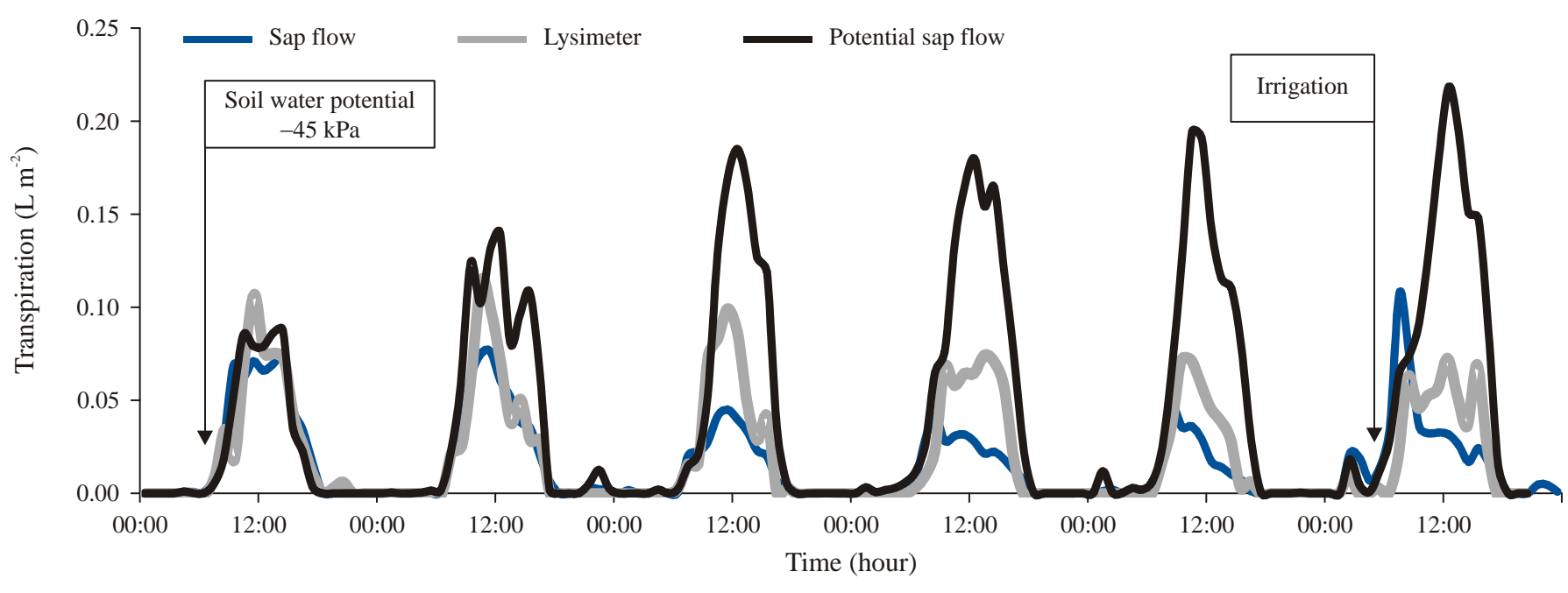

Figure 4. Transpiration path per unit leaf area of an orange plant in soil undergoing drying process estimated by means of sap flow and weighing lysimeters as compared to another plant under adequate water supply (potential sap flow) 


\section{CONCLUSIONS}

1. The heat balance method proved to be accurate in estimating daily transpiration which accompassed the available energy of the system, underestimating on average $4.6 \%$ daily transpiration in orange plants, and overestimating on average $0.3 \%$ daily transpiration in mango plants, when compared to the values obtained by lysimeters under adequate water supply conditions in soil.

2. Under water deficit conditions, the method of heat balance underestimated on average $16 \%$ transpiration in orange plants.

\section{LITERATURE CITED}

Alarcón, J. J.; Domingo, R.; Green, S. R.; Sánchez-Blanco, M. J.; Rodríguez, P.; Torrecillas, A. Sap flow as an indicator of transpiration and the water status of young apricot trees. Plant and Soil, v.227, p.77-85, 2000.

Bauerle, W. L.; Post, C. J.; Mcleod, M. F.; Dudley, J. B.; Toler, J. E. Measurement and modeling of the transpiration of a temperate red maple container nursery. Agricultural and Forest Meteorology, v.114, p.45-57, 2002.

Cermak, J.; Kucera, L.; Zideck, V. Xylem water flow in crack willow tree (Salix fragillis L.) in relation to do diurnal changes of environment. Oecologia, v.64, p.145-151, 1984.

Coelho Filho, M. A. Determinação da transpiração máxima em um pomar jovem de lima ácida 'Tahitil (Citrus latifolia Tan) e sua relação com a evapotranspiração de referência. Piracicaba: ESALQ/USP, 2002.91p. Tese Doutorado

Coelho Filho, M. A.; Angelocci, L. R.; Campeche, L. F. S. M.; Folegatti, M. V.; Bernardes, M. S. Field determination of young acid lime plants transpiration by the stem heat balance method. Scientia Agricola, v.62, n.3, p.240-247, 2005 a.

Coelho Filho, M. A.; Angelocci, L. R.; Rojas, J. D.; Campeche, L. F. S. M.; Folegatti, M. V. Relações entre transpiração máxima, área foliar e evapotranspiração de referência em pomar jovem de lima ácida 'Tahiti'. Revista Brasileira de Agrometeorologia, v.12, n.2, p.265-274, 2004.

Coelho Filho, M. A.; Angelocci, L. R.; Vasconcelos, M. R. B.; Coelho, E. F. Estimativa da área foliar de plantas de lima ácida 'Tahiti' usando métodos não-destrutivos. Revista Brasileira de Fruticultura, v.27, n.1, p.163-167, 2005b.

Cohen, Y.; Fuchs, M.; Green, G. C. Improvement of the heat pulse method for determining sap flow in trees. Plant, Cell and Environment, v.4, p.391-397, 1981.

D’Angiolella, G. L. B.; Castro Neto, M. T.; Coelho, E. F. Tendências climáticas para os tabuleiros costeiros da região de Cruz das Almas, BA. In: Congresso Brasileiro de Engenharia Agrícola, 27, 1998, Poços de Caldas. Anais... Lavras: SBEA, 1998, p.43.

David, T. S.; Ferreira, M. I.; Pereira, J. S. Transpiration from a mature Eucalyptus globules plantation in Portugal during a spring-summer period of progressively higher water deficit. Oecologia, v.110, p.153-159, 1997.
Delgado-Rojas, J. S.; Angelocci, L. R.; Folegatti, M. V.; Coelho Filho, M. A. Desempenho da sonda de dissipação térmica na medida da transpiração de plantas jovens de lima ácida. Engenharia Agrícola, v.27, n.2, p.404-413, 2007.

Gomide, R. L.; Durães, F. O. M.; Kobayashi, M. K.; Machado, R. A. F. Caracterização de estresse hídrico de duas linhagens de milho (Zea mays L.) com sondas de fluxo de seiva. Revista Brasileira de Milho e Sorgo, v.4, n.3, p.344-354, 2005.

Granier, A. Une neuvelle méthode pour la mesure du flux de sève brute dans le tronc des arbres. Annales des Sciences Forestières, v.42, p.193-200, 1985.

Marin, F. R.; Angelocci, L. R.; Pereira, A. R. ; Villa Nova, N. A.; Sentelhas, P. C. Sap flow and evapotranspiration in an irrigated citrus orchard. Revista Brasileira de Agrometeorologia, v.9, p.219-226, 2001.

Nakai, T.; Abe, H.; Muramoto, T.; Nakao, T. The relationship between sap flow rate and diurnal change of tangential strain on inner bark in Cryptomeria japonica saplings. Journal of Wood Science, v.51, p.441-447, 2005

Oliveira, G. X. S. Determinação da transpiração em mangueiras (Mangifera indica L.), através do fluxo de seiva, sua relação com a evapotranspiração e área foliar. Cruz das Almas: UFBA, 2005. 40p. Dissertação Mestrado

Oliveira, G. X. S.; Coelho Filho, M. A.; Pereira, F. A. de C.; Castro Neto, M. T. de, Coelho, E. F. Relações entre transpiração máxima, área foliar de quatro variedades de mangueira e evapotranspiração de referência. In: Congresso Brasileiro de Agrometeorologia, 14, 2005, Campinas. Anais... Campinas: SBA, 2005. CD-Rom.

Sakuratani, T. A heat balance method for measuring water flux in the stem of intact plants. Journal of Agricultural Meteorology, v.37, p.9-17, 1981.

Santos, R. M.; Oliveira, A. S.; Vellame, L. M.; Brandão, F. J. C. Montagem e acurácia de um sistema experimental de pesagem para calibração de sensores de umidade do solo. Ciência e Agrotecnologia, v.30, n.6, p.1162-1169, 2006.

Steinberg, S.; Bavel, C. H. M.; Cornelius, H. M. van. A gauge to measure mass flow rate sap in steams and trunks of wood plants. Journal of the American Society for Horticultural Science, v.114, n.3, p.466-472, 1989.

Tarara, J. M.; Ferguson, J. C. Two algorithms for variable power control of heat-balance sap flow gauges under high flow rates. Agronomy Journal, v.98, p.830-838, 2006.

Trejo-Chandia, J. E. Avaliação do método de balanço de calor na estimativa da transpiração de tomateiros, plantas de milho e mudas de limoeiro. Piracicaba: ESALQ/USP, 1997. 75p. Tese Doutorado

Vellame, L. M.; Coelho Filho, M. A.; Paz, V. P. S. Transpiração em mangueira pelo método Granier. Revista Brasileira de Engenharia Agrícola e Ambiental, v.13, n.5, p.516-523, 2009.

Vellame, L. M.; Oliveira, A. S . Development and testing of a tension reading system for use with field tensiometers. Magistra, v.17, n.1, p.15-22, 2005.

Weibel, F. P.; Vos, J. A. Transpiration measurements on apple trees with an improved stem heat balance method. Plant and Soil, v.166, p.203-219, 1994.

Wheeler, A. J.; Ganji, A. R. Introduction to engineering experimentation. New Jersey: Prentice Hall, 1996. 415p. 